\title{
Use of a Seed Scarifier for Detection and Enumeration of Galls of Anguina and Rathayibacter Species in Orchard Grass Seed
}

\author{
Steve C. Alderman, Plant Pathologist, and Douglas M. Bilsland, Senior Faculty Research Assistant, USDA-ARS \\ National Forage Seed Production Research Center, 3450 SW Campus Way, Corvallis, OR 97331; John A. Gries- \\ bach, Nematologist, and Gene M. Milbrath, Plant Pathologist, Oregon Department of Agriculture, Plant Division, \\ 635 Capitol St. NE, Salem, OR 97301; Norman W. Schaad, Plant Pathologist, USDA-ARS Foreign Disease-Weed \\ Science Research Unit, 1301 Ditto Ave, Ft. Detrick, MD 21702; and Elena Postnikova, Research Associate, De- \\ partment of Plant Pathology, University of Nebraska, Lincoln
}

\begin{abstract}
Alderman, S. C., Bilsland, D. M., Griesbach, J. A., Milbrath, G. M., Schaad, N. W., and Postnikova, E. 2003. Use of a seed scarifier for detection and enumeration of galls of Anguina and Rathayibacter species in orchard grass seed. Plant Dis. 87:320-323.

Seed galls, caused by Anguina spp., are normally detected visually in cereals such as wheat and barley. However, in grasses such as orchard grass, the presence of galls induced by Anguina or Rathayibacter spp. are difficult to detect visually due to their infrequent occurrence and masking by lemmas and paleas. To develop improved seed assays for the presence of the nematode and bacterial galls, a small scarifier was used to remove lemmas and paleas without causing major damage to seeds or galls. Following scarification, the galls were visually identified and manually counted under a dissecting microscope. Using the scarifier, several orchard grass seed lots were screened for Anguina and Rathayibacter spp. The percentage of samples of orchard grass seed harvested in the Willamette Valley of Oregon during 1996, 1997, and 2000 containing galls of Anguina sp. were 37, 46, and 48, respectively. The percentage of samples containing bacterial galls with Rathayibacter sp. was 27,31, and 40, respectively. Total galls with Anguina sp. per $25 \mathrm{~g}$ of orchard grass sample ranged from 1 to 24. The mean of Anguina sp. galls per sample in 1996, 1997, and 2000 were 4, 5, and 5, respectively. Total galls with bacteria per $25 \mathrm{~g}$ of sample ranged from 27 to 40; mean number of galls per sample in 1996, 1997, and 2000 were, 6,5 , and 11, respectively. This is the first report confirming the presence of Rathayibacter sp. galls in orchard grass in Oregon.
\end{abstract}

Additional keywords: cocksfoot, Dactylis, grass seed, grass seed nematode, Rathay's disease, seed conditioning, seed pathology

The nematode genus Anguina includes species that infect the inflorescence of grasses, replacing the seeds with galls. Important species include $A$. agrostis, $A$. funesta, A. graminis, and A. tritici (22). An uncharacterized species occurs in orchard grass (Dactylis glomerata L.) in England (21), Denmark (12), and the United States $(7,8,13)$. In England, Southey (21) reported less than $0.1 \%$ galls (wt) from infested orchard grass seed samples. The occurrence of Anguina spp. in orchard grass in Oregon has been documented $(6,7)$, although quantitative data on the percentage

Corresponding author: S. Alderman

E-mail: aldermas@onid.orst.edu

Accepted for publication 7 November 2002.

Publication no. D-2003-0214-02R

This article is in the public domain and not copyrightable. It may be freely reprinted with customary crediting of the source. The American Phytopathological Society, 2003. of infested seed is lacking. Although Anguina spp. are believed to occur at low levels, presence of nematodes in seeds prevents exports to countries which have a zero tolerance restriction for Anguina spp.

Southey (21) reported that galls of an Anguina sp. in orchard grass in England were shrunken, fusiform, smaller than normal seed, and purplish. Hardison and Jensen (7) reported the occurrence of an Anguina sp. on several plants of cv. Akora orchard grass on an experimental farm at Granger, OR, but described the galls as short and thick, and their photographs clearly illustrate the morphological characters. In addition, the highly distorted seed heads observed by Hardison and Jensen (7) differed from the near normal appearing heads reported by galls in Oregon have not been reported and it is not clear if gall morphology in commercial orchard grass seed production fields in Oregon differs from that reported from England (21). Southey (21). Subsequent observation of
The current method used by the Oregon Department of Agriculture (ODA) to assay seed for Anguina spp. involves soaking the seed in water for $24 \mathrm{~h}$, fracturing the seed in a blender at medium speed, sieving on 40and 100-mesh sieves to remove debris, and collecting the nematodes on a 400-mesh sieve. The sample is examined for Anguina spp. under $\times 10$ to $\times 60$ magnification (6). Anguina spp. are verified at $\times 400$ or $\times 1000$ magnification, depending on the condition of the specimen. The method is time consuming and tedious because of fine debris suspended in the sample, and it is not well suited for quantitative assessment of infestation levels. A method to extract whole galls could provide a significant improvement in detection and assessment in seed lots.

Anguina spp. are known to vector Rathayibacter spp. (16). In orchard grass, the bacterial infection caused by $R$. rathay $i$ is commonly referred to as Rathay's disease, after its original description by Rathay in Germany (20). Distorted, shrunken inflorescences characterize Rathay's disease with little to no seed production. The inflorescences contain yellowish bacterial ooze that may extend beyond the seed and collect on the inflorescence $(5,17,20)$. Rathay's disease can be a serious problem of orchard grass in England $(5,21)$, and what is believed to be Rathay's disease is becoming more common in Oregon (S. Alderman, personnel observations). Based on descriptions of disease symptoms in England (21) and Germany (20), the disease in Oregon is assumed to be associated with $R$. rathayi. However, the bacterium associated with the disease in Oregon has not been described. The Anguina sp. causing galls in orchard grass is believed to vector a Rathayibacter sp. In grasses such as Lolium rigidum (3) and Vulpia myuros (15) infection by $R$. toxicus results in discrete yellow bacterial galls, which develop from bacterial colonization of Anguina-induced galls. Bacterial galls have not been documented in orchard grass. $R$. tritici is known to infect wheat but not orchard grass and has not been reported in wheat in Oregon. 
Little is known of the AnguinaRathayibacter association in orchard grass. Studies have been limited by the infrequent occurrence of the nematode galls, the inability to detect the galls when covered by lemmas and paleas, and the inability to detect the nematode in seed heads severely infested with $R$. rathayi (17). The objectives of this study were: (i) to develop a method for the detection and quantitative enumeration of nematode and bacterial galls from orchard grass seed; (ii) characterize the galls; (iii) estimate the level of infested seed from samples of orchard grass seed lots; (iv) estimate the ratio of nematode and bacterial galls within seed lots; and (v) identify the bacterium associated with the galls. A preliminary report was published (1).

\section{MATERIAL AND METHODS}

Description of scarifier and description and enumeration of galls. Preliminary tests indicated that a seed scarifier powered by compressed air (Hoffman, Mfg., Albany, OR) was effective in removal of the lemma and palea without damage to the seed, although only small (1 to $3 \mathrm{~g}$ ) samples could be processed. In association with Mater International, Inc. (Corvallis, OR), an improved model with a sample capacity of at least $5 \mathrm{~g}$ was designed and fabricated. The model is now commercially available from Mater International, Inc. (Model PSS1000) (Fig. 1). Orchard grass seed infested with Anguina sp. was obtained from the ODA and used for development of the assessment protocol. The ODA tests official seed samples for pests and diseases, including Anguina spp., as required for export. To determine the optimum sample size and time for removal of the lemma and palea, seed samples of 1 to $8 \mathrm{~g}$ were processed for $0.5,1.0$, $1.5,2.0,2.5$, and $3.0 \mathrm{~min}$ intervals while pressurized at $50 \mathrm{lb} / \mathrm{in}^{2}$. For each treatment combination, seeds with or without lemmas and paleas were manually separated and weighed. Mean weight of seed with or without lemmas and paleas was based on four replicate weights of 100 seed.

All seed samples examined were obtained from the Oregon State University Seed Laboratory (OSUSL). The OSUSL conducts germination, purity, and other seed tests required to meet seed certification requirements, and samples submitted are considered representative of seed lots. Approximately 250 samples of orchard grass from seed production fields in Oregon are submitted to the OSUSL annually for testing, typically for germination and purity as required for seed certification. One hundred samples $(25 \mathrm{~g})$ of seed submitted to the OSUSL were obtained from each 1996, 1997, and 2001 harvest. Samples were selected at random and stored dry in paper envelopes under ambient laboratory conditions prior to assessment.
For enumeration of galls, $25 \mathrm{~g}$ of seed from the OSUSL was processed in the scarifer (5 $\mathrm{g}$ at a time) at $50 \mathrm{lb} / \mathrm{in}^{2}$ for $90 \mathrm{~s}$. Fine material was removed from the seed with an air column seed separator (Dakota Blower, Hoffman Mfg.) adjusted to remove lightweight debris but not lightweight seeds or galls. The lightweight fraction was periodically checked under a dissecting microscope at $\times 10$ to $\times 40$ magnification to verify that small seeds or galls were not included with the lightweight debris. Galls and small seeds were separated from the healthy (larger) seeds with a rectangular mesh $(0.51 \times 3.91 \mathrm{~mm}$ opening) sieve (Crippen Mfg., Alma, MI). The material that passed through the sieve was examined under a dissecting scope and galls were visually identified and counted. Galls of Anguina sp. were verified by examination of galls bisected in water on a glass slide. In the presence of water, the nematodes rapidly rehydrate and expand, and can be easily seen under the dissecting scope. Remaining seeds were coarsely chopped with a razor blade, placed in water for $1 \mathrm{~min}$, and examined for any galls that may have escaped detection. After scarification, the bright yellow bacterial galls were easy to visually detect among the seeds.

Field observations. Surveys were conducted in four commercial orchard grass fields near Corvallis, OR on 23 May and 19 June 2002. Approximately 100 seed heads were collected at 3 to 10 sites in each of the four fields where Rathay's disease was present. Florets were examined for galls under a dissecting microscope with dark field illumination. Suspect galls of Anguina sp. were removed and dissected in water to verify presence of nematodes. Anguina sp. was confirmed at

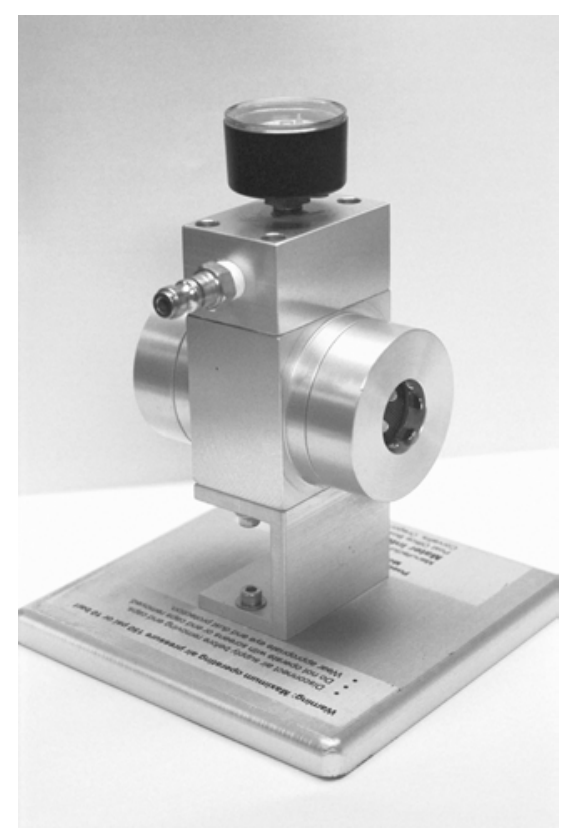

Fig. 1. Air powered scarifier (model PSS1000, Mater International, Inc., Corvallis, OR) $\times 400$ magnification. Bacterial galls were identified by a lemon yellow, translucent appearance.

Identification of Rathayibacter spp. Ten intact bacterial galls were selected at random from a pool of galls collected during the course of the survey. Bacteria were isolated by soaking galls in 1 to $2 \mathrm{ml}$ of water for $1 \mathrm{~h}$ and streaking samples on nutrient broth-yeast extract (NBY) agar (18). After incubating for 3 to 4 days at $25^{\circ} \mathrm{C}$, suspect colonies were transferred to NBY agar. To confirm the identity of the suspected bacteria as Rathayibacter, 3 of 10 strains from galls collected in the Oregon survey (FH-132, 133, and 134) were compared to the type strains of the cereal pathogen $R$. tritici, FH-5 (National Collection of Plant Pathogenic Bacteria (NCPPB)1845, York, England), grass pathogens $R$. rathayi, FH-95 (International Collection of Microorganisms from Plants 2574, Auckland, New Zealand), and $R$. toxicus, FH-79 (CS-14 (NCPPB 3552) from I. Riley, University of Adelaide, Australia. The following physiological and morphological tests were conducted for identification of Rathayibacter spp. (4): gram reaction (18), acid fast (24), catalase (24), hydrolysis of esculin (19), oxidase reaction (18), utilization of sorbitol and acetate (4), and growth on triphenyltetrazolium-chloride (TTC) agar (4).

\section{RESULTS}

Description and enumeration of galls. The percentage of seeds in which lemmas and paleas were removed (naked caryopses) was 75 to $95 \%, 96$ to $100 \%$, and 99 to $100 \%$ after $0.5,1.0$, and $1.5 \mathrm{~min}$, respectively (Fig. 2). Samples greater than $6 \mathrm{~g}$ exceeded the capacity of the scarifier, resulting in few naked caryopses. Mean weight of a single naked caryopsis was $0.86 \mathrm{mg}$ and that of a seed covered with lemma and palea was $1.16 \mathrm{mg}$ (based on four replicate weights of 100 seed).

Field observations. The percentage of samples with galls of Anguina sp. recovered from seed samples during 1996, 1997,

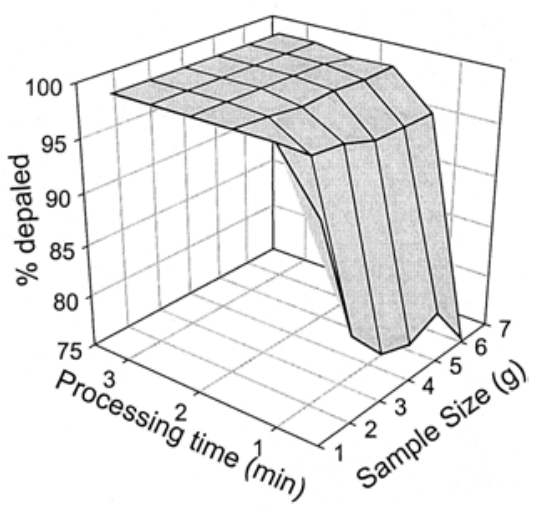

Fig. 2. Relationship among sample size, processing time, and resulting removal of lemma and palea by a PS1000 seed scarifier. 
Table 1. Numbers of nematode (Anguina sp.) and bacterial sp. (Rathayibacter sp.) galls recovered from $25 \mathrm{~g}$ of seed samples of orchard grass grown in the Willamette Valley of Oregon during 1996, 1997, and 2000

\begin{tabular}{lcc}
\hline Year & Anguina sp. & Rathayibacter sp. \\
\hline 1996 & & 27 \\
Percent samples with galls ${ }^{\mathrm{a}}$ & 37 & $1-24$ \\
Galls per sample (range) & $1-18$ & $6 \pm 5$ \\
Galls per sample (mean \pm s.d.) & \\
1997 & $4 \pm 4$ & 31 \\
Percent samples with galls & & $1-17$ \\
Galls per sample (range) & 46 & $5 \pm 4$ \\
Galls per sample (mean \pm s.d.) & $1-17$ & \\
2000 & $5 \pm 5$ & 40 \\
Percent samples with galls & & $1-39$ \\
Galls per sample (range) & 48 & $11 \pm 8$ \\
Galls per sample (mean \pm s.d.) & $1-24$ & \\
\hline
\end{tabular}

a Based on 100 25-g samples.

${ }^{\mathrm{b}}$ s.d. = standard deviation

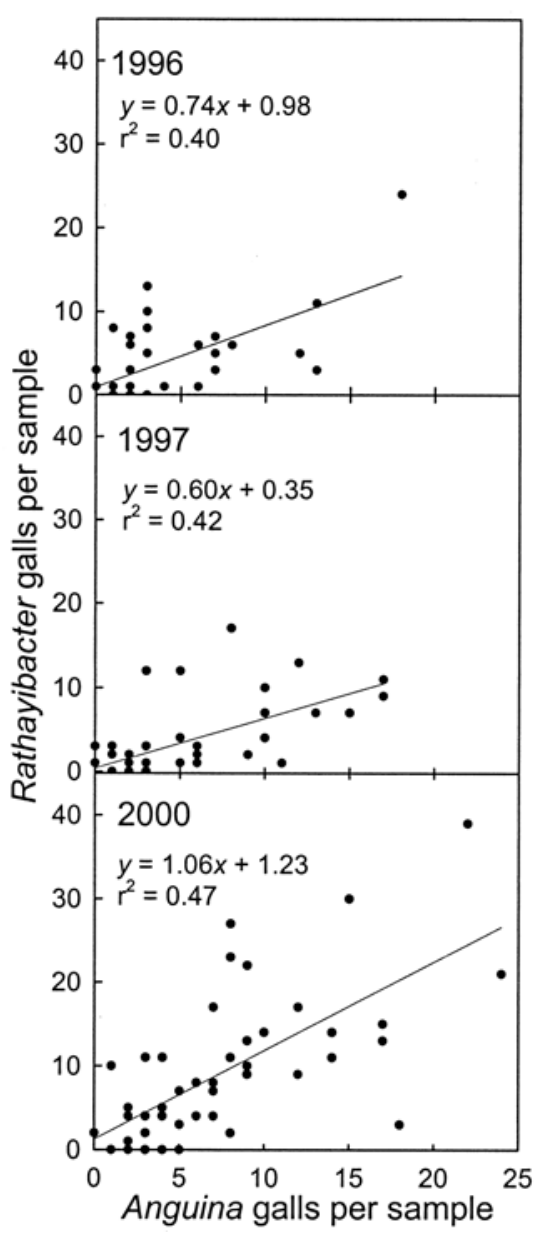

Fig. 3. Relationship between the number of galls of Anguina sp. and Rathayibacter sp. collected in 1996, 1997, and 2000.

and 2000 were 37,46 , and 48, respectively. Total galls per $25 \mathrm{~g}$ of sample ranged from 1 to 24 , with mean galls per sample ranging from 4 to 7 (Table 1). The percentage of samples with galls of Rathayibacter sp. recovered from seed samples from 1996, 1997, and 2000 were 27,31 , and 40, respectively. Total galls per $25 \mathrm{~g}$ of sample ranged from 1 to 39 , with mean galls ranging from 5 to 11 (Table 1). The ratio of samples with Rathayibacter sp. to samples

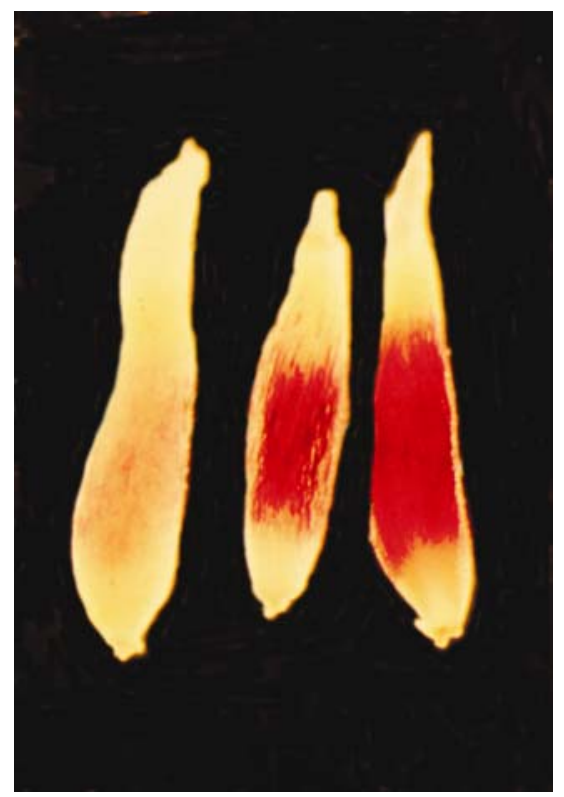

Fig 5. Fresh galls of Anguina sp. from field collected orchard grass.

lected from the field (Fig. 5). Surface texture was finely striate along the length of the gall. Panicles and florets infected with Anguina sp. appeared similar to noninfected panicles and florets.

Bacterial galls were similar in size and shape to the Anguina galls, but were lemon yellow throughout and semitranslucent to opaque with a matte to satin sheen on the surface (Fig. 4). Galls measured 1.0 to 2.5 $\mathrm{mm} \times 0.4$ to $0.5 \mathrm{~mm}$ (mean $1.9 \pm 0.4 \times 0.4$ \pm 0.1 ), based on 20 galls. Average weight per gall was $0.17 \mathrm{mg}$. Fresh bacterial galls collected from the field were similar to dried galls.

A few galls were observed to be yellow with purple coloration in the lower to middle portion of the gall. When fractured and placed in water, some remains of nematodes were found but the galls were predominantly of bacterial composition.

Identification of Rathayibacter spp. The three representative strains from Oregon and $R$. rathayi were gram positive, nonacid fast, and catalase positive. They hydrolyzed esculin, but failed to produce acid from sorbitol, could not utilize acetate, and were oxidase negative. They produced round, nonmucoid yellow colonies on NBY and grew on TTC agar. Results with $R$. tritici were the same except acetate was utilized, as expected. These results confirm that the bacteria associated with galls were Rathayibacter sp.

\section{DISCUSSION}

The PS1000 seed scarifier proved very effective in removal of the lemmas and paleas from seeds, permitting a visual inspection of seeds. Minimal damage was observed on the surface of galls, although there was fracturing of some galls into halves or more rarely thirds. Some galls, 
which lacked purple coloration, escaped visual examination but were detected when the seeds were chopped and placed in water. Seed testing procedures used by the ODA are variable depending on the efficiency of the grinding and the uncertainty of fracturing galls within the samples. The method takes several days and preparations are often clouded with debris, making visual detection of nematodes time consuming and difficult. The scarifier provides a more rapid and reliable alternative for detection of Anguina spp. in seed samples. However, additional studies will be needed to determine the relative limits of detection associated with the two methods prior to recommendation of any changes in ODA testing protocols for Anguina spp.

Our observations differ from those of Hardison and Jensen (7), who found larger, thicker galls on several volunteer plants of orchard grass (cv. Akora) at the Oregon Agricultural Experiment Station at Granger, OR. We believe this Anguina sp., which also produced considerable distortion in the seed head, represents a separate nematode species; there are no other known reports of its occurrence in Oregon. The shrunken, elongated galls of Anguina sp. from orchard grass seed that we observed in Oregon were similar to those associated with $R$. rathayi in England (21). Our bacterial characterization test results are consistent with the descriptions of Rathayibacter spp. (4).

Rathayibacter spp. produce a gummosis in the grass inflorescence $(5,21)$. Small pieces of stem tissue with transparent yellow residue from the bacterial gummosis were seen in some infested seed samples. However, discrete galls were observed in all infested samples. This is the first report of bacterial galls in orchard grass. The bright yellow galls are similar to those produced by $R$. toxicus in L. rigidum $(3,10)$ and V. myuros (15).

In $L$. ridigum, the nematode galls are pointed, shorter than noninfested seed, and black with a clear tip. Bacterial galls are similar in shape but yellow with a clear tip (10). Price et al. (14) described the nematode galls from L. ridigum as bottle shaped with the rind containing a purplish or brownish pigment and a mean of 740 nematodes per gall. Southey (21) reported 500 to 2,000 Anguina sp. larvae per gall from orchard grass, a range consistent with observations in this study.

Since galls produced by $R$. toxicus contain a toxin that can severely affect grazing animals $(9,11,23)$, it is important to know if the Rathayibacter sp. in orchard grass might be $R$. toxicus. There are no known reports of toxicity associated with $R$. rathayi infected orchard grass. Our results indicate that $R$. rathayi is the causal agent of bacterial gummosis (Rathay's disease) in orchard grass in Oregon. In the case of A. funesta infecting L. rigidum, the bacteria adhere to the cuticle of the nematode and the nematode serves as a vector (2). Riley and McKay (16) reported specificity of bacterial strains of Rathayibacter with Anguina. Work is underway to identify the exact species of Rathayibacter strains associated with Anguina sp. infecting orchard grass in Oregon.

The weight of Anguina and Rathayibacter galls was found to be much less than orchard grass seed. Additional studies will be needed to determine if galls can be removed, based on weight, during seed cleaning operations. Some lots contain a high proportion of lightweight seed. It is also not known what proportion of seed galls are returned to fields with lightweight seed during combining at harvest to serve as inoculum for the next season.

The scarifier proved useful in enumeration of galls of Anguina and Rathayibacter. The means to remove lemmas and paleas for seeds will not only facilitate quantitative studies of nematode and bacterial galls but may improve visual detection of other grass seed diseases or anomalies that are masked by lemmas and paleas.

\section{LITERATURE CITED}

1. Alderman, S. C., Griesbach, J. A., and Milbrath, G. M. 2001. Assessment of Anguina and Clavibacter in orchardgrass. Pages 23-24 in: Seed Production Research at Oregon State University, USDA-ARS Cooperating. William C. Young III ed., Oregon State University Dept. Crop and Soil Science Ext/CrS 115.

2. Bird, A, and Stynes, B. A. 1977. The morphology of a Corynebacterium sp. parasitic on annual rye grass. Phytopathology 67:828830.

3. Bird, A., Stynes, B. A., and Thomson, W. W. 1980. A comparison of nematode and bacteria-colonized galls induced by Anguina agrostis in Lolium rigidum. Phytopathology 70:1104-1109.

4. Davis, M. J. and Vidaver, A. K. 2000. Coryneform Plant Pathogens. Pages 218-234 in: Laboratory Guide for Identification of Plant Pathogenic Bacteria. N. W. Schaad, J. B. Jones, and W. Chun, eds. The American Phytopathological Society, St. Paul, MN.

5. Dowson W. J., and d'Oliveira, M. 1935. On the occurrence of Aplanobacter rathayi E. F. Smith on Dactylis glomerata in England. Ann. Appl. Biol. 22:23-26.

6. Griesbach, J. A., Chitambar, J. J., Hamerlynk, M. J., and Duarte, E. O. 1999. A comparative analysis of extraction methods for the recovery of Anguina sp. from grass seed samples. J. Nematol. (Suppl.) 31:635-640.

7. Hardison, J. R., and Jensen, H. J. 1953. A seed nematode observed in orchard grass in Oregon. Plant Dis. Rep. 37:388-389.

8. Jensen, H. J. 1961. Nematodes affecting Oregon Agriculture. Oregon State Univ. Agric. Exp. Stn. Bull. 579.
9. Lanigen G. W., Payne, A. L., and Frahn, J. L. 1976. Origin of toxicity in parasitised annual ryegrass (Lolium rigidum). Aust. Vet. J. 52:244-246.

10. Mahoney, G., Sykes, W., Brown, R., and Cade, J. 1985. Annual ryegrass toxicity. Agnote, Agdex 400/652. F. D. Atkinson Government Printer, Melbourne.

11. McKay, A. C., Ophel, K. M., Reardon, T. B., and Gooden, J. M. 1993. Livestock deaths associated with Clavibacter toxicus/Anguina sp. infection in seedheads of Agrostis avenacea and Polypogon monspeliensis. Plant Dis. 77:635-641.

12. Nobel M., de Tempe, J., and Neergaard, P. 1959. An Annotated list of seed-borne diseases. Proc. Int. Seed Test. Assoc. 24:1-159.

13. Powers, T. O., Szalanski, A. L., Mullin, P. G., Harris, T. S., Bertozzi, T., and Friesbach, J. A. 2001. Identification of seed gall nematodes of agronomic and regulatory concern with PCRRFLP of ITS-1. J. Nematol. 33:191-194.

14. Price, P. C., Fisher, J. M., and Kerr, A. 1979. Annual ryegrass toxicity: parasitism of $\mathrm{Lo}$ lium rigidum by a seed-gall forming nematode (Anguina sp.). Ann. Appl. Biol. 91:359369.

15. Riley, I. T. 1995. Vulpia myuros and the annual ryegrass toxicity organisms, Anguina funesta and Clavibacter toxicus. Fundam. Appl. Nematol. 18:595-598.

16. Riley, I. T. and McKay, A. C. 1990. Specificity of the adhesion of some plant pathogenic microorganisms to the cuticle of nematodes in the genus Anguina (Nematoda: Anguinidae). Nematologica 36:90-103.

17. Sabet, K. A. 1954. On the host range and systemic position of the bacteria responsible for the yellow slime disease of wheat (Triticum vulgare Vill.) and cocksfoot grass (Dactylis glomerata L.). Ann. Appl. Biol. 41:606611.

18. Schaad, N.W. 2000. Initial Identification Pages 1-15 in: Laboratory Guide for Identification of Plant Pathogenic Bacteria. N. W. Schaad, J. B. Jones, and W. Chun, eds. The American Phytopathological Society, St. Paul, MN.

19. Schaad, N.W. and Jones, J.B. 2000. Xanthomonas. Pages 175-199 in: Laboratory Guide for Identification of Plant Pathogenic Bacteria. N. W. Schaad, J. B. Jones, and W. Chun, eds. The American Phytopathological Society, St. Paul, MN.

20. Smith, E. F. 1914. Bacteria in relation to plant disease, Vol. 3. Carnegie Inst. Wash. Publ. 27 Press of Gibson Brothers, Washington, DC.

21. Southey, J. F. 1969. A gall-forming nematode (Anguina sp.) parastic on Cocksfoot grass. Plant Pathol. 18:164-166.

22. Southey, J. F., Topham, P. B., and Brown, D. J. F. 1990. Taxonomy of some species of Anguina Scopoli, 1777 (sensu Brzeski, 1981) forming galls on Gramineae: value of diagnostic characteristics and present status of nominal species. Rev. Nematol. 13:127142 .

23. Stynes, B. A., Petterson, D. S., Lloyd, J., Payne, A. L., and Lanigan, G. W. 1979. The production of toxin in annual ryegrass, $\mathrm{Lo}$ lium rigidum, infected with a nematode, $A n$ guina sp., and Coynebacterium rathayi. Aust. J. Agric. Res. 30:201-209.

24. Wilson, G. S., and Miles, A. A. 1957. Topley and Wilson's Principles of Bacteriology and Immunity. 4th ed. Vol 1. The Williams \& Wilkins Company, Baltimore, MD. 